\title{
PENGARUH POLA ASUH ORANG TUA TERHADAP PENGENDALIAN EMOSI ANAK KELAS VII SMP NEGERI 2 KASIHAN BANTUL TAHUN PELAJARAN 2015/2016
}

\author{
Ika Ernawati \\ Program Studi Bimbingan dan Konseling \\ Fakultas Keguruan dan Ilmu Pendidikan \\ Universitas PGRI Yogyakarta \\ E-mail: ikaernawatipgri@gmail.com
}

\begin{abstract}
Abstrak
Penelitian ini bertujuan untuk mengetahui pengaruh pola asuh orang tua terhadap pengendalian emosi anak Kelas VII SMP Negeri 2 Kasihan Bantul Tahun Pelajaran 2015/2016. Populasi dalam penelitian ini adalah siswa kelas VII SMP Negeri 2 Kasihan tahun pelajaran 2015/2016, sejumlah 132 siswa. Sampel dalam penelitian ini sebanyak 100 siswa. Teknik pengumpulan data menggunakan kuesioner yang bersifat tertutup. Hasil penelitian menunjukkan bahwa ada pengaruh positif dan signifikan pola asuh orang tua terhadap pengendalian emosi anak Kelas VII SMP Negeri 2 Kasihan Bantul Tahun Pelajaran 2015/2016, ditunjukkan dari nilai $\mathrm{R}=0,352$ dan $\mathrm{F}$ Hitung $=13,847$ dengan $\mathrm{p}=$ $0,000(\mathrm{p}<0,05)$. Artimya semakin baik pola asuh orang tua terhadap anak maka semakin baik pula pengendalian emosi anak tersebut. Demikian juga sebaliknya semakin kurang pola asuh orang tua terhadap anak maka semakin kurang pula pengendalian emosi anak tersebut.
\end{abstract}

Kata kunci: pola asuh, pengendalian emosi

\begin{abstract}
This study aims to determine the effect of parental care pattern on the emotional control of children Class VII SMP Negeri 2 Kasihan Bantul Lesson 2015/2016. The population in this study is the students of grade VII SMP Negeri 2 Kasihan 2015/2016 school year, a number of 132 students. The sample in this research is 100 students. Technique of collecting data using questionnaire which is closed. The results showed that there was a positive and significant influence of parenting pattern on the emotional control of children of Class VII of SMP Negeri 2 Kasihan Bantul Lesson Year 2015/2016, shown from the value of $R=0.352$ and $F$ Count $=13.847$ with $p=0,000(p<0,05)$. Artimya the better parenting pattern of the child the better the emotional control of the child. Likewise on the contrary the less parenting pattern of the child, the less the emotional control of the child.
\end{abstract}

Keywords: parenting, emotional control

\section{Info Artikel}

Diterima April 2018, disetujui Mei 2018, diterbitkan Juni 2018 


\section{PENDAHULUAN}

Kehidupan emosional anak mulai berkembang sejak anak sudah dapat berinteraksi dengan lingkungan keluarga. Hubungan sosial dalam keluarga yang sehat/harmonis dapat memuat pesan pembelajaran emosional. Di sini anak mampu untuk mengendalikan emosinya ketika orang tua belum dapat memenuhi permintaannya dengan segera, atau ketika sang kakak menghadapi ujian sang adik berusaha mengurangi volume menonton talangan televisi agar tidak mengganggu kakaknya yang sedang belajar. Perilaku semacam itu yang menjadi tolok ukur adalah orang tuanya.,misalnya sikap ibu yang tidak langsung marah ketika anak tidak sengaja memecahkan gelas, tapi menasehati dengan sabar agar lain kali lebih hati-hati.

Dalam pola pengasuhan anak, orang tua yang menomorduakan pembelajaran emosional bagi anak, cenderung melakukan pelbagai upaya untuk menyenangkan anak, untuk menjaga perasaan anak agar tidak kecewa, sakit hati dan lain-lain. Bahkan ketika anak berbuat tidak sepantasnya kepada orang tua, memutuskan untuk menyerah karena khawatir anaknya akan sakit hati kalau ditegur. Akhirnya anak cenderung dimanja, justru untuk menghindari agar jangan sampai anak mengamuk, atau membentak-bentak orang tua.

Ilustrasi pola pengasuhan anak sebagaimana terurai di atas sangat tidak mendukung tercapainya kecerdasan emosional anak. Karena anak selalu terpenuhi permintaannya. Bila hal ini berlangsung dari kecil saat usia pra sekolah, maka saat anak mulai memasuki bangku sekolah akan terbentuk sikap kepribadian anak yang selalu merasa berkuasa dan selalu dipenuhi permintaannya yang diterapkan di sekolah, di lingkungan bermain dan sebagainya. Karena dari kecil selalu terpenuhi permintaannya kepada orang tua secara emosional anak tidak mampu belajar bagaimana memahami kondisi orang tua yang belum dapat memenuhi permintaannya.

Tantangan yang dihadapi anak Kelas VII SMP umumnya berasal dari harapan-harapan terbaik para orang tua terhadap anak-anak mereka. Umumnya para orang tua menginginkan anak-anak mereka berprestasi di sekolah. Ada orang tua yang menetapkan target anaknya harus masuk tiga besar atau sepuluh besar.

Anak yang dibesarkan dalam keluarga yang mengedepankan pembelajaran emosional dalam pola asuhnya, cenderung lebih siap dalam menghadapi tantangan. Hubungan sosial yang terjadi dalam keluarga harmonis memberi kesempatan anak mengalami pembelajaran emosional. Pola pengasuhan yang dilakukan orang tua akan berpengaruh terhadap kemampuan dalam mengendalikan emosi. Keluarga merupakan lingkungan sosial utama yang berpengaruh terhadap perkembangan emosi anak. Pola asuh akan 
menentukan keberhasilan sosialisasi norma sosial dan perilaku yang dilakukan oleh orang tua. Efektivitas penanaman norma sosial dan perilaku sosial, menyebabkan anak mampu mengembangkan perilaku yang adekuat, dan mampu mengendalikan emosi dalam interaksi dengan lingkungan sosialnya.

Berdasarkan latar belakang masalah di atas maka penulis tertarik untuk melakukan penelitian dengan judul Pengaruh Pola Asuh Orang Tua terhadap Pengendalian Emosi Anak Kelas VII SMP Negeri 2 Kasihan Bantul Tahun Pelajaran 2015/2016.

\section{KAJIAN TEORI}

\section{Pola Asuh Orang Tua}

Pengertian Pola Asuh Orang Tua

Euis Sunarti (2004 : 93), pola asuh orang tua merupakan pola perilaku orang tua yang paling menonjol atau yang paling dominan dalam menangani anaknya sehari-hari. Pola orang tua dalam mendisiplinkan anak, dalam menanamkan nilai-nilai hidup, dalam mengajarkan keterampilan hidup, dan dalam mengelola emosi. Dari beberapa cara penilaian pola pengasuhan, yang paling sensitif adalah dengan mengukur kesan anak tentang pola perlakuan orang tua terhadapnya. Kesan mendalam dari seorang anak mengenai bagaimana dia diperlakukan orang tuanya, itulah pola atau gaya pengasuhan. Adapun Khabib Thoha (2001 : 109) mengemukakan bahwa pola asuh orang tua adalah suatu cara terbaik yang dapat ditempuh orang tua dalam mendidik anak sebagai perwujudan dari rasa tanggung jawab kepada anak.

Berdasarkan pendapat ahli di atas, bahwa pola asuh orang tua adalah pola perilaku orang tua yang paling menonjol atau yang paling dominan yang dapat ditempuh orang tua dalam mendidik anak sebagai perwujudan dari rasa tanggung jawab kepada anak.

\section{Jenis Pola Asuh Orang Tua}

Agus Dariyo (2004 : 97) membagi bentuk pola asuh orang tua menjadi empat, yaitu :

1. Pola Asuh Otoriter (parent oriented)

Ciri-cri dari pola asuh ini, menekankan segala aturan orang tua harus ditaati oleh anak. Orang tua bertindak semena-mena, tanpa dapat dikontrol oleh anak. Anak harus menurut dan tidak boleh membantah terhadap apa yang diperintahkan oleh orang tua. Dalam hal ini, anak seolah-olah mejadi "robot", sehingga ia kurang inisiatif, merasa takut tidak percaya diri, pencemas, rendah diri, minder dalam pergaulan tetapi disisi lain, anak bisa memberontak, nakal, atau melarikan diri dari kenyataan, misalnya dengan menggunakan narkoba. Dari segi positifnya, anak yang dididik dalam pola asuh ini, cenderung akan menjadi disiplin yakni mentaati peraturan. Akan tetapi bisa jadi, ia hanya mau 
menunjukkan kedisiplinan di hadapan orang tua, padahal dalam hatinya berbicara lain, sehingga ketika di belakang orang tua, anak bersikap dan bertindak lain. Hal itu tujuannya semata hanya untuk menyenangkan hati orang tua. Jadi anak cenderung memiliki kedisiplinan dan kepatuhan yang semu.

2. Pola Asuh Permisif (children centered)

Sifat pola asuh ini, yakni segala aturan dan ketetapan keluarga di tangan anak. Apa yang dilakukan oleh anak diperbolehkan orang tua. Orang tua menuruti segala kemauan anak. Anak cenderung bertindak semenamena, tanpa pengawasan orang tua. Ia bebas melakukan apa saja yang diinginkan. Dari sisi negatif lain, anak kurang disiplin dengan aturan-aturan sosial yang berlaku. Bila anak mampu menggunakan kebebasan tersebut secara bertanggung jawab, maka anak akan menjadi seorang yang mandiri, kreatif, inisiatif dan mampu mewujudkan aktualisasinya.

3. Pola Asuh Demokratis

Kedudukan antara orang tua dan anak sejajar. Suatu keputusan diambil bersama dengan mempertimbangkan kedua belah pihak. Anak diberi kebebasan yang bertanggung jawab, artinya apa yang dilakukan oleh anak tetap harus dibawah pengawasan orang tua dan dapat dipertanggung jawabkan secara moral. Orang tua dan anak tidak dapat berbuat semena-mena. Anak diberi kepercayaan dan dilatih untuk mempertanggung jawabkan segala tindakannya. Akibat positif dari pola asuh ini, anak akan menjadi seorang individu yang mempercayai orang lain, bertanggung jawab terhadap tindakan-tindakannya, tidak munafik, jujur. Namun akibat negatif, anak akan cenderung merongrong kewibawaan otoritas orang tua, kalau segala sesuatu harus dipertimbangkan anak dan orang tua.

4. Pola Asuh Situsional

Pada pola asuh ini orang tua tidak menerapkan salah satu tipe pola asuh tertentu. Tetapi kemungkinan orang tua menerapkan pola asuh secara fleksibel, luwes dan disesuaikan dengan situasi dan kondisi yang berlangsung saat itu.

\section{Pengendalian Emosi \\ Pengertian Emosi}

Anthony Dio Martin (2003 : 24) menyatakan emosi, pada prinsipnya menggambarkan perasaan manusia menghadapi situasi berbeda. Oleh karena itu emosi merupakan reaksi manusiawi terhadap berbagai situasi nyata. Emosi terdiri dari emosi yang menyenangkan dan emosi yang tidak menyenangkan. Adapun Abdul Rahman Shaleh dan Muhbib Abdul 
Wahab (2004 : 151) menyatakan bahwa emosi adalah suatu keadaan jiwa sebagai akibat adanya peristiwaperistiwa yang umumnya datang dari luar, dan peristiwa-peristiwa tersebut pada umumnya menimbulkan kegoncangan-kegoncangan pada individu yang bersangkutan.

Berdasarkan pendapat para ahli di atas, maka dapat disimpulkan bahwa emosi adalah perasaan manusia menghadapi situasi berbeda berupa peristiwa-peristiwa yang umumnya datang dari luar, dan peristiwaperistiwa tersebut pada umumnya menimbulkan kegoncangankegoncangan pada individu yang bersangkutan.

\section{Ciri-Ciri Emosi}

Menurut Syamsu Yusuf (2008 : 116), Emosi sebagai suatu peristiwa psikologis mengandung ciri-ciri sebagai berikut :

1. Lebih bersifat subjektif daripada peristiwa psikologis lainnya, seperti pengamatan dan berpikir.

2. Bersifat fluktuatif (tidak tetap).

3. Banyak bersangkut paut dengan peristiwa pengenalan panca indera.

\section{Manfaat Emosi}

Kompleksitas dan proses emosi manusia jauh lebih berkembang dari hewan. Bagi manusia, emosi bukan lagi hanya berfungsi sebagai untuk survival, atau sekedar bertahan hidup seperti pada hewan. Menurut Anthony Dio Martin Martin (2003 : 93 - 94), ada manfaat-manfaat lain yang lebih menarik dari emosi manusia, yaitu :

1. Pembangkit energi (energizer).

Emosi memberikan

kegairahan dalam kehidupan manusia.

2. Pembawa pesan (messenger)

Kita tidak perlu diberi tahu untuk tidak sembarangan membuat lelucon jika rekan anda sedang menunjukkan wajah cemberut, apalagi jika air mata menetes di pipi. Petunjuk fisik ini cukup menggambarkan perasaan mereka yang sedang tidak enak saat itu. Atau misalnya apaila melihat anak pulang dengan senyuman lebar di hari pengumuman naik kelas, maka dapat dipastikan anak tersebut naik kelas..

3. Memperkuat pesan atau informasi yang disampaikan (reinforcer)

Para artis, aktor, pemain drama, orator atau komunikator ulung sangat memahami hal ini. Misalnya saat kita mengatakan kalimat "Saya tidak bisa menerima keputusan ini" dengan nada biasabiasa saja seperti sedang membaca koran. Bandingkan tatkala sambil memukul meja dan diliputi rasa marah kita berkata " Saya tidak bisa menerima keputusan ini !", maka sangat berbeda pesan yang ditangkap. Perbedaan terletak pada reaksi emosi yang diberikan. Inilah yang dimaksudkan dengan emosi mempertegas informasi yang ingin disampaikan. 
4. Penyeimbang kehidupan kita (balancer)

Emosi memungkinkan kita menjaga proses homeostatis dalam diri kita. Umpamanya, ketika kita sedih karena kehilangan seseorang yang dicintai, kita menangis. Tangis tersebut dapat memberi rasa lega bagi kita. Atau misalnya kita menyaksikan suatu adegan yang sangat lucu di acara televisi, kita tertawa terbahak-bahak. Gelak tawa tersebut juga memberi kelegaan bagi kita. Contoh lainnya, ketika suasana yang sedang sangat serius, berjam-jam berdiskusi tapi tak kunjung mencapai titik temu, tiba-tiba ada teman menyeletuk dengan komentar lucu. Suasana berubah menjadi kegembiraan, menjadi penyeimbang atas situasi yang tegang.

Berdasarkan pendapat di atas, maka dapat disimpulkan emosi dapat bermanfaat untuk memberikan kegairahan dalam kehidupan manusia, pembawa pesan melalui bahasa tubuh yang disebabkan emosinya, memperkuat pesan yang ingin disampaikan, dan njaga proses homeostatis dalam diri manusia.

\section{Jenis-jenis Emosi}

Menurut Syamsu Yusuf (2008 : 117), emosi dapat dikelompokkan ke dalarn dua bagian, yaitu emosi sensoris dan emosi kejiwaan (psikis).
1. Emosi sensoris, yaitu emosi yang ditimbulkan oleh rangsangan dari luar terhadap tubuh, seperti: rasa dingin, manis, sakit, lelah, kenyang, dan lapar.

2. Emosi psikis, yaitu emosi yang mempunyai alasan-alasan kejiwaan. Yang termasuk emosi ini, di antaranya adalah:

a. Perasaan Intelektual, yaitu yang mempunyai sangkut paut dengan ruang lingkup kebenaran. perasaan ini diwujudkan dalam bentuk :

1) Rasa yakin dan tidak yakin terhadap suatu hasil karya ilmiah.

2) Rasa gembira karena mendapat suatu kebenaran.

3) Rasa puas karena dapat menyelesaikan persoalanpersoalan ilmiah yang harus dipecahkan

b. Perasaan Sosial, yaitu perasaan yang menyangkut hubungan dengan orang lain, baik bersifat perorangan maupun kelompok. Wujud perasaan ini seperti :

1) Rasa solidaritas.

2) Persaudaraan.

3) Simpati.

4) Kasih sayang dan sebagainya.

c. Perasaan Susila, yaitu perasaan yang berhubungan dengan nilai-nilai baik dan buruk atau etika (moral). Contohnya :

1) Rasa tanggung jawab (responsibility) 
2) Rasa bersalah apabila melanggar norma.

3) Rasa tenteram dalam menaati norma.

d. Perasaan Keindahan (estetis), yaitu perasaan yang berkaitan erat dengan keindahan dari sesuatu, baik bersifat kebendaan maupun kerohanian.

e. Perasaan Ketuhanan. Salah satu kelebihan manusia sebagai makhluk Tuhan, dianugerahi fitrah (kemampuan atau perasaan) untuk mengenal Tuhannya. Dengan kata lain, manusia dikaruniai insting religius (naluri beragama). Karena memiliki fitrah ini, kemudian manusia dijuluki sebagai "Homo Divinans" dan "Homo Religius" , yaitu sebagai makhluk yang berkeTuhan-an atau makhluk beragama.

Rena Descartes (dalam Abdul Rahman Shaleh dan Muhbib Abdul Wahab, 2004 : 168), menyatakan bahwa sejak lahir manusia mempunyai enam emosi dasar, yaitu :

1. Cinta

2. Kegembiraan

3. Keinginan

4. Benci

5. Sedih, dan

6. Kagum

Berdasarkan pendapat di atas, maka dapat disimpulkan bahwa emosi merupakan bagian tak terpisahkan dari manusia yang memiliki akal, dan semua manusia memiliki emosi dasar yang sama.

\section{METODE PENELITIAN}

Penelitian ini dilaksanakan di SMP Negeri 2 Kasihan Bantul dari bulan September sampai dengan bulan Nopember 2015. Dalam penelitian ini terdapat dua buah variabel, yaitu satu variabel bebas dan satu variabel terikat.

1. Variabel Bebas : Pola Asuh Orang Tua (X)

2. Variabel Terikat : Pengendalian Emosi (Y)

Populasi dalam penelitian ini adalah seluruh siswa kelas VII SMP Negeri 2 Kasihan Bantul tahun pelajaran 2015/2016 berjumlah 132 anak. Dalam penelitian ini tidak seluruh anggota populasi dijadikan subyek penelitian, hanya sebagian anggota populasi diambil sebagai sampel dengan teknik quota random sampling sebanyak 100 siswa.

Dalam penelitian ini metode pengumpulan data yang digunakan adalah angket/kuesioner. Adapun jenis angket/kuesioner yang digunakan dalam penelitian ini adalah angket/kuesioner tertutup karena sudah disediakan jawabannya, sedangkan apabila ditinjau dari bentuknya termasuk angket/kuesioner pilihan ganda, karena responden tinggal memilih salah satu jawabawan diantara alternatif jawaban yang tersedia, dipandang dari jawaban yang diberikan adalah kuesioner langsung, dan dipandang dari bentuknya maka 
termasuk rating scale (skala bertingkat).

Instrumen yang digunakan untuk pengambilan data penelitian, perlu diuji validitas dan reliabilitasnya. Hal ini dikarenakan kualitas data penelitian sangat tergantung dari kualitas instrumen penelitian. Pengujian validitas dan reliabilitas dilakukan melalui uji coba penelitian terhadap 20 responden di kelas VII SMP Negeri 2 Kasihan Bantul yang merupakan subyek di luar sampel. Pengujian validitas dan reliabilitas butir dilakukan dengan menggunakan SPSS (Statistical Product and Service Solution) 16.0 Suatu butir dikatakan sahih apabila didapatkan nilai korelasi yang positif dan nilai $\mathrm{p}<0,05$.

Untuk kuesioner pola asuh orang tua, dari 25 butir pertanyaan didapatkan semua item pertanyaan sahih. Adapun untuk kuesioner pengendalian emosi, dari 20 butir pertanyaan didapatkan semua butir pertanyaan sahih. Berdasarkan hal tersebut, maka semua pertanyaan dalam kuesioner pola asuh orang tua dan kuesioner pengendalian emosi dapat dipergunakan untuk pengambilan data penelitian.

Hasil pengujian reliabilitas dengan SPSS (Statistical Product and Service Solution) 16.0 untuk kuesioner pola asuh orang tua didapatkan nilai koefisien Alpha (rtt) sebesar 0,929, maka dapat disimpulkan bahwa kuesioner pola asuh orang tua reliabel/andal. Adapun untuk kuesioner pengendalian emosi didapatkan nilai koefisien Alpha (rtt) sebesar 0,912, maka dapat disimpulkan bahwa kuesioner pengendalian emosi reliabel/andal.

\section{Teknik Analisis Data}

Analisis Deskriptif

Analisis deskriptif dimaksudkan untuk menggambarkan data penelitian yang diperoleh dari hasil penyebaran angket. Agar data penelitian dapat digambarkan, maka dilakukan penafsiran terhadap data tersebut dengan menggunakan kalimat kualitatif. Adapun metode untuk menafsirkan data penelitian digunakan metode kurva normal. Data penelitian dikelompokkan menjadi menjadi sangat baik, baik, tidak baik, dan sangat tidak baik, dengan kriteria :

1. $\mathrm{M}+1,5 \mathrm{SD}$ sampai dengan Skor tertinggi = Sangat Baik

2. $\mathrm{M}$ sampai dengan $\mathrm{M}+1,5 \mathrm{SD}=$ Baik

3. $\mathrm{M}-1,5$ SD sampai dengan $\mathrm{M}=$ Tidak Baik

4. Skor terendah sampai dengan $M$ 1,5 SD = Sangat Tidak Baik

Analisis Regresi Linier Sederhana

Penelitian ini merupakan penelitian korelasi, dan untuk menghitung besarnya pengaruh, menggunakan metode bivariate statistik yaitu statistik yang dapat digunakan oleh peneliti untuk menerangkan pengaruh satu variabel terhadap variabel lainnya.

Teknik a data menggunakan teknik Regresi Linier Sederhana 
dilakukan Dengan bantuan komputer program SPSS (Statistical Product and Service Solution). Untuk menerima atau menolak data tersebut ditetapkan pada taraf signifikan $5 \%$ dengan $\mathrm{db}=$ $\mathrm{m}: \mathrm{N}-\mathrm{m}-1$. Apabila harga Fhitung lebih kecil dari Ftabel 0,05 maka pengaruh variabel bebas terhadap variabel terikat adalah dinyatakan diterima.

\section{HASIL PENELITIAN PEMBAHASAN} DAN

\section{Variabel Pola Asuh Orang Tua}

Data tentang pola asuh orang tua diperoleh melalui kuesioner sebanyak 25 butir, yang memiliki rentang skor 25-100. Berdasarkan data yang telah diperoleh dan kemudian dihitung menggunakan SPSS (Statistical Product and Service Solution) 16.0 maka diperoleh hasil sebagai berikut.

\section{Tabel 1}

Tabel Output Deskripsi Data Pola Asuh Orang Tua Statistics

\begin{tabular}{|c|c|c|}
\hline \multicolumn{3}{|c|}{ Pola Asuh Orang Tua } \\
\hline $\mathrm{N}$ & Valid & 100 \\
\hline & Missing & 0 \\
\hline & & 73.8300 \\
\hline & & 73.5000 \\
\hline Mo & & $78.00^{\circ}$ \\
\hline & tion & 9.74011 \\
\hline & & 94.870 \\
\hline & & 46.00 \\
\hline & & 93.00 \\
\hline Su & & 7383.00 \\
\hline
\end{tabular}

Berdasarkan tabel diperoleh Mean $(\mathrm{M})=73,83 ; \operatorname{Median}(\mathrm{Me})=$ 73,5; Modus $(\mathrm{Mo})=78 ;$ Std.
Deviation $(\mathrm{SD})=9.74$; Skor terendah 46; Skor tertinggi 93. Adapun distribusi frekuensi dapat dilihat pada tabel berikut :

Tabel 2

Distribusi Frekuensi Data Pola Asuh Orang Tua

\begin{tabular}{|cc|c|c|c|}
\hline \multicolumn{2}{|c|}{ Interval } & $\mathrm{f}$ & $\mathrm{f} \%$ & fk\%-naik \\
\hline $90-100$ & 9 & 9.00 & 100 \\
\hline $79-89$ & 22 & 22.00 & 91.00 \\
\hline $68-78$ & 42 & 42.00 & 69.00 \\
\hline $57-67$ & 25 & 25.00 & 27.00 \\
\hline $46-56$ & 2 & 2.00 & 2.00 \\
\hline $35-45$ & 0 & 0.00 & 0.00 \\
\hline $24-34$ & 0 & 0.00 & 0.00 \\
\hline \multicolumn{6}{|c|}{ Total } & 100 & 100 & -- \\
\hline
\end{tabular}

Selanjutnya skor tersebut dikategorikan menjadi tiga kategori yaitu baik, cukup, dan kurang. Kategori tersebut didasarkan pada simpangan baku dan rerata ideal. Dipilihnya tiga kategori ini karena distribusi gejalanya berdistribusi normal dan kriteria ini menggunakan jarak pengukuran yang sama. Penggolongannya sebagai berikut :

1. Kategori baik = $(+1 \mathrm{SDi})$ Skor tertinggi

2. Kategori cukup $=(-1 \mathrm{SDi})-(+$ 1SDi)

3. Kategori kurang $=$ Skor terendah $-($ - 1SDi)

Atas dasar rumus di atas, maka pengkategorian dapat dilihat pada tabel berikut : 
Tabel 3

Klasifikasi Data Pola Asuh Orang Tua

\begin{tabular}{|c|c|c|c|}
\hline $\begin{array}{c}\text { Kelas } \\
\text { Interval }\end{array}$ & $\begin{array}{r}\text { Fre } \\
\text { kue } \\
\text { nsi }\end{array}$ & $\begin{array}{c}\text { Frekuensi } \\
\text { Persentase } \\
(\%)\end{array}$ & $\begin{array}{c}\text { Katego } \\
\text { ri }\end{array}$ \\
\hline-100 & 44 & 44.00 & Baik \\
\hline $50-75$ & 55 & 55.00 & Cukup \\
\hline $25-50$ & 1 & 1.00 & Kurang \\
\hline Jumlah & 100 & 100,00 & \\
\hline
\end{tabular}

Berdasarkan tabel di atas, maka dapat dinyatakan bahwa data pola asuh orang tua meliputi $44 \%$ berada pada kategori baik, 55\% berada pada kategori cukup, dan $1 \%$ berada pada kategori kurang. Dengan demikian dilihat dari Mean (M) 73,83 yang berada pada kelas interval $50<\mathrm{X} \leq 75$ pola asuh orang tua siswa kelas VII SMP Negeri 2 Kasihan Bantul Tahun Pelajaran 2015/2016 cenderung berkategori cukup.

\section{Variabel Pengendalian Emosi}

Data tentang pengendalian emosi diperoleh melalui kuesioner tertutup dengan jumlah item sebanyak 20 butir yang memiliki rentang skor 20-100. Berdasarkan data yang telah diperoleh dan kemudian dihitung menggunakan SPSS (Statistical Product and Service Solution) 16.0 maka diperoleh hasil sebagai berikut.
Tabel 4

Tabel Output Deskripsi Data Pengendalian Emosi

Statistics
\begin{tabular}{|l|r|}
\hline \multicolumn{2}{c|}{ Pengendalian Emosi } \\
\hline \multicolumn{1}{|c|}{ Valid } & 100 \\
Mean & 0 \\
Median & 56.7200 \\
Mode & 56.5000 \\
Std. Deviation & $50.00^{\mathrm{a}}$ \\
Variance & 6.81513 \\
Minimum & 46.446 \\
Maximum & 38.00 \\
Sum & 71.00 \\
\hline
\end{tabular}

Berdasarkan tabel diperoleh Mean $(\mathrm{M})=56,72 ;$ Median $(\mathrm{Me})=$ 56,5; Modus (Mo) $=50 ;$ Std. Deviation $(\mathrm{SD})=6.82$; Skor terendah 38; Skor tertinggi 71. Adapun distribusi frekuensi dapat dilihat pada tabel berikut :

\section{Tabel 5}

\section{Distribusi Frekuensi Data Pengendalian Emosi}

\begin{tabular}{|c|c|c|c|c|}
\hline \multicolumn{2}{|c|}{ Interval } & $\mathbf{f}$ & f\% & fk\%-naik \\
\hline 72 & -80 & 0 & 0.00 & 100 \\
\hline 63 & $\begin{array}{l}-71 \\
\end{array}$ & 23 & 23.00 & 100.00 \\
\hline 54 & -62 & 43 & 43.00 & 77.00 \\
\hline 45 & -53 & 31 & 31.00 & 34.00 \\
\hline 36 & $-\quad 44$ & 3 & 3.00 & 3.00 \\
\hline 27 & -35 & 0 & 0.00 & 0.00 \\
\hline 18 & -26 & 0 & 0.00 & 0.00 \\
\hline & tal & 100 & 100 & -- \\
\hline
\end{tabular}

Selanjutnya skor tersebut dikategorikan menjadi tiga kategori 
yaitu baik, cukup, dan kurang. Kategori tersebut didasarkan pada simpangan baku dan rerata ideal. Dipilihnya tiga kategori ini karena distribusi gejalanya berdistribusi normal dan kriteria ini menggunakan jarak pengukuran yang sama. Penggolongannya sebagai berikut :

1. Kategori baik = $(+1 \mathrm{SDi})$ Skor tertinggi

2. Kategori cukup $=(-1 \mathrm{SDi})-(+$ 1SDi)

3. Kategori kurang $=$ Skor terendah - ( - 1SDi)

Atas dasar rumus di atas, maka pengkategorian dapat dilihat pada tabel berikut :

Tabel 6

Klasifikasi Data Pengendalian

Emosi

\begin{tabular}{|c|c|c|c|}
\hline $\begin{array}{c}\text { Kelas } \\
\text { Interval }\end{array}$ & $\begin{array}{c}\text { Fre } \\
\text { kue } \\
\text { nsi }\end{array}$ & $\begin{array}{c}\text { Frekuensi } \\
\text { Persentas } \\
\mathbf{e}(\boldsymbol{\%})\end{array}$ & Kategori \\
\hline $60-80$ & 30 & 30.00 & Baik \\
\hline $40-60$ & 68 & 68.00 & Cukup \\
\hline $20-40$ & 2 & 2.00 & Kurang \\
\hline Jumlah & 100 & 100,00 & \\
\hline
\end{tabular}

Berdasarkan tabel di atas, maka dapat dinyatakan bahwa data pengendalian emosi meliputi $30 \%$ berada pada kategori baik, $68 \%$ berada pada kategori cukup, dan $2 \%$ berada pada kategori kurang. Dengan demikian dilihat dari Mean (M) 56,72 yang berada pada kelas interval $40<$ $\mathrm{X} \leq 60$ berarti pengendalian emosi siswa kelas VII SMP Negeri 2 Kasihan Bantul Tahun Pelajaran
2015/2016 cenderung berkategori cukup.

Teknik Analisis regresi linier sederhana digunakan untuk mengetahui pengaruh pola asuh orang tua terhadap pengendalian emosi anak kelas VII SMP Negeri 2 Kasihan Bantul tahun pelajaran 2015/2016. Berdasarkan hasil analisis regresi linier sederhana di atas maka diketahui harga koefisien regresi b yaitu 0,246 sedangkan konstanta (a) sebesar 38,544. Harga-harga tersebut dapat ditulis dalam bentuk persamaan regresi sebagai berikut:

$\mathrm{Y}=\mathrm{a}+\mathrm{b} \cdot \mathrm{X}$

$Y=38,544+0,246 . X$

Dari persamaan regresi linier sederhana tersebut dapat diterangkan bahwa: Nilai 38,544 merupakan konstanta yang menunjukkan jika ada pengaruh pola asuh orang tua maka pengendalian emosi siswa akan meningkat sebesar 38,544. Pola asuh orang tua mempunyai koefisien regresi 0,246 berarti bahwa setiap kenaikan variabel pola asuh orang tua sebesar 1 maka pengendalian emosi akan naik sebesar $24,6 \%$ dengan asumsi variabel yang lain tetap. Berdasarkan tabel, diketahui bahwa variabel $X$ (pola asuh orang tua) signifikan.

Dengan menggunakan tingkat kesalahan $\alpha=5 \%$ berarti variabel bebas tersebut berpengaruh terhadap variabel terikat $\mathrm{Y}$ (pengendalian emosi), dapat disimpulkan bahwa variabel pola asuh orang tua memiliki pengaruh yang signifikan terhadap 
pengendalian emosi siswa kelas VII SMP Negeri 2 Kasihan Bantul tahun pelajaran 2015/2016.

\section{Pengujian Hipotesis}

Hipotesis merupakan jawaban sementara atas masalah yang harus dirumuskan. Hipotesis ini harus diuji kebenarannya secara empiris. Dalam penelitian ini terjadi dua hipotesis yaitu hipotesis nol (Ho) dan hipotesis alternatif (Ha). Hipotesis nol (Ho) yaitu hipotesis yang menyatakan tidak ada pengaruh variabel bebas terhadap variabel tergantung, sedangkan hipotesis alternatif (Ha) yaitu hipotesis yang menyatakan ada pengaruh variabel bebas terhadap variabel tergantung.

Dari analisis yang dilakukan dengan komputer program SPSS (Statistical Product and Service Solution) 16.0 hasilnya diperoleh sebagai berikut.

1. Hipotesis $\mathrm{Nol}(\mathrm{Ho})$

Adapun hipotesis nol (Ho) yang diajukan dalam penelitian ini adalah tidak ada pengaruh yang positif dan signifikan pola asuh orang tua terhadap pengendalian emosi anak kelas VII SMP Negeri 2 Kasihan Bantul tahun pelajaran 2015/2016.

Berdasarkan hasil analisis data yang diperoleh nilai $\mathrm{R}=$ 0,352, Fhitung $=13,847$, dengan $p$ $=0,000$ atau $0,000<0,05$. Hal ini berarti terdapat pengaruh positif dan signifikan pola asuh orang tua terhadap pengendalian emosi siswa. Dengan demikian hipotesis nol (Ho) pada penelitian ini yang berbunyi tidak ada pengaruh positif dan signifikan pola asuh orang tua terhadap pengendalian emosi anak kelas VII SMP Negeri 2 Kasihan Bantul tahun pelajaran 2015/2016 dinyatakan ditolak.

2. Hipotesis Alternatif (Ha)

Berdasarkan hasil analisis data yang diperoleh nilai $\mathrm{R}=$ 0,352 , Fhitung $=13,847$, dengan $p$ $=0,000$ atau $0,000<0,05$. Hal ini berarti terdapat pengaruh positif dan signifikan pola asuh orang tua terhadap pengendalian emosi anak. Sedangkan hipotesis alternatif (Ha) yang diajukan dalam penelitian ini adalah ada pengaruh positif dan signifikan pola asuh orang tua terhadap pengendalian emosi anak kelas VII SMP Negeri 2 Kasihan Bantul tahun pelajaran 2015/2016 dinyatakan diterima.

\section{KESIMPULAN DAN IMPLIKASI Kesimpulan}

Berdasarkan hasil penelitian dan pembahasan yang telah diuraikan pada BAB IV, maka dapat disimpulkan halhal sebagai berikut : Ada pengaruh yang positif dan signifikan pola asuh orang tua terhadap pengendalian emosi anak kelas VII SMP Negeri 2 Kasihan Bantul tahun pelajaran 2015/2016, dengan diperoleh $\mathrm{R}=$ 0,352 , Fhitung $=13,847$, dengan $\mathrm{p}=$ $0,000<0,05$. Artinya semakin baik pola asuh orang tua terhadap anak maka semakin baik pula pengendalian 
emosi anak tersebut. Demikian juga sebaliknya semakin kurang pola asuh orang tua terhadap anak maka semakin kurang pengendalian emosi anak tersebut.

\section{Implikasi}

Berdasarkan kesimpulan hasil penelitian ini, akan disampaikan beberapa implikasi baik teoritis maupun praktis, sebagai berikut : berdasarkan hasil penelitian semakin memperkuat teori yang menyatakan bahwa terdapat pengaruh yang positif dan signifikan pola asuh orang tua terhadap pengendalian emosi anak, sehingga ini dapat dijadikan bahan pertimbangan bagi pihak sekolah untuk dapat lebih menciptakan dan mengembangkan program kegiatan yang menarik, menyenangkan bagi siswa dan lebih optimal serta didukung peran serta orang tua dalam upaya membentuk pengendalian emosi anak yang lebih baik. Dan bagi peneliti, maka hasil penelitian ini dapat dijadikan sebagai salah satu referensi maupun salah satu sumber teori yang dapat digunakan sebagai materi penunjang dalam penelitian yang berhubungan dengan materi tersebut.

\section{DAFTAR PUSTAKA}

Abdul Rahman Shaleh dan Muhbib Abdul Wahab. 2004. Psikologi suatu pengantar (dalam perspektif islam). Edisi pertama. Jakarta : Kencana.
Anthony Dio Martin. 2003. Emotional quality management : refleksi, revisi dan revitalisasi hidup melalui kekuatan emosi. Cetakan kedua. Jakarta : Arga.

Agus Dariyo. 2004. Psikologi perkembangan temaja. Jakarta: Ghalia Indonesia.

Euis Sunarti. 2004. Mengasuh dengan hati: tantantan yang menyenangkan. Jakarta : PT. Elex Media Komputindo.

Gulo, W. 2007. Metodologi penelitian. Jakarta : PT. Grasindo.

Khabib Thoha 2001. Kapita selekta pendidikan islam. Yogyakarta : Pustaka Pelajar.

Mohammad Idrus. 2007. Metode penelitian ilmu-ilmu sosial (pendekatan kualitatif dan kuantitatif). Yogyakarta : UII Press.

Nurul Zuriah. 2009. Metodologi Penelitian Sosial dan Pendidikan : Teori - Aplikasi. Jakarta : Bumi Aksara.

Saifudin Azwar. 2000. Reliabilitas dan validitas. Yogyakarta : Pustaka Pelajar.

Sudjana. 2005. Metoda Statistika. Bandung : Tarsito.

Sugiyono. 2005. Statistika untuk penelitian. Bandung : Alfabeta.

Suharsimi Arikunto. 2002. Prosedur penelitian suatu pendekatan 
praktek. Jakarta : PT. Rineka Cipta.

Sutrisno Hadi. 2000. Metodologi research jilid 2. Yogyakarta : Andi Offset.

Syamsu Yusuf. 2008. Psikologi perkembangan anak dan remaja. Bandung : PT. Remaja Rosdakarya.

Ulber Silalahi. 2009. Metode Penelitian Sosial. Jakarta : PT. Refika Aditama. 